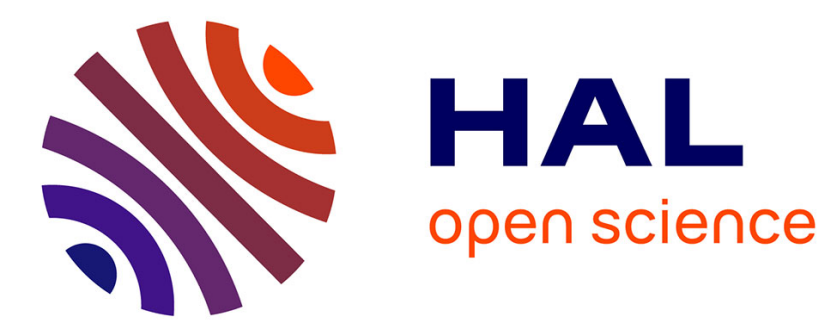

\title{
Carbon Price Efficiency Lock-in and Path Dependence in Urban Forms and Transport Infrastructure
}

Paolo Avner, Jun Rentschler, Stéphane Hallegatte

\section{To cite this version:}

Paolo Avner, Jun Rentschler, Stéphane Hallegatte. Carbon Price Efficiency Lock-in and Path Dependence in Urban Forms and Transport Infrastructure. World Bank Policy Research Working Papers, 2014, 6941, pp.1 - 26. 10.1596/1813-9450-6941 . hal-01083739

\section{HAL Id: hal-01083739 \\ https: / hal-enpc.archives-ouvertes.fr/hal-01083739}

Submitted on 17 Nov 2014

HAL is a multi-disciplinary open access archive for the deposit and dissemination of scientific research documents, whether they are published or not. The documents may come from teaching and research institutions in France or abroad, or from public or private research centers.
L'archive ouverte pluridisciplinaire HAL, est destinée au dépôt et à la diffusion de documents scientifiques de niveau recherche, publiés ou non, émanant des établissements d'enseignement et de recherche français ou étrangers, des laboratoires publics ou privés. 


\title{
Policy Research Working Paper 6941
}

\section{Carbon Price Efficiency}

\section{Lock-in and Path Dependence in Urban Forms and Transport Infrastructure}

\author{
Paolo Avner \\ Jun Rentschler \\ Stéphane Hallegatte
}

The World Bank

Urban Disaster and Risk Management Department

Urban Development and Resilience Unit $\&$

Climate Change Group

Office of the Chief Economist

June 2014 
Policy Research Working Paper 6941

\section{Abstract}

This paper investigates the effect of carbon or gasoline taxes on commuting-related $\mathrm{CO}_{2}$ emissions in an urban context. To assess the impact of public transport on the efficiency of the tax, the paper investigates two exogenous scenarios using a dynamic urban model (NEDUM-2D) calibrated for the urban area of Paris: (i) a scenario with the current dense public transport infrastructure, and (ii) a scenario without. It is shown that the price elasticity of $\mathrm{CO}_{2}$ emissions is twice as high in the short run if public transport options exist. Reducing commuting-related emissions thus requires lower (and more acceptable) tax levels in the presence of dense public transportation. If the goal of a carbon or gasoline tax is to change behaviors and reduce energy consumption and $\mathrm{CO}_{2}$ emissions (not

to raise revenues), then there is an incentive to increase the price elasticity through complementary policies such as public transport development. The emission elasticity also depends on the baseline scenario and is larger when population growth and income growth are high. In the longer run, elasticities are higher and similar in the scenarios with and without public transport, because of larger urban reconfiguration in the latter scenario. These results are policy relevant, especially for fastgrowing cities in developing countries. Even for cities where emission reductions are not a priority today, there is an option value attached to a dense public transport network, since it makes it possible to reduce emissions at a lower cost in the future.

This paper is a product of the Urban Development and Resilience Unit, Urban Disaster and Risk Management Department and the Office of the Chief Economist, Climate Change Group. It is part of a larger effort by the World Bank to provide open access to its research and make a contribution to development policy discussions around the world. Policy Research Working Papers are also posted on the Web at http://econ.worldbank.org. The authors may be contacted at pavner@ worldbank.org.

The Policy Research Working Paper Series disseminates the findings of work in progress to encourage the exchange of ideas about development issues. An objective of the series is to get the findings out quickly, even if the presentations are less than fully polished. The papers carry the names of the authors and should be cited accordingly. The findings, interpretations, and conclusions expressed in this paper are entirely those of the authors. They do not necessarily represent the views of the International Bank for Reconstruction and Development/World Bank and its affliated organizations, or those of the Executive Directors of the World Bank or the governments they represent. 


\title{
Carbon Price Efficiency: Lock-in and Path Dependence in Urban Forms and Transport Infrastructure
}

\author{
Paolo AVNER ${ }^{(a, b, d)}$, Jun RENTSCHLER ${ }^{(c)}$, Stéphane HALLEGATTE ${ }^{(d) 1}$ \\ (a) Centre International de Recherche sur l'Environnement et le Développement (CIRED), Paris, France \\ (b) Association pour la Promotion de la Recherche sur l'Economie du Carbone (APREC), Paris, France \\ (c) University College London, London, UK \\ (d) The World Bank, Washington DC, USA
}

JEL Codes: H23, H21, R14, R42, C63

Keywords: Spatial lock-in, Carbon tax efficiency, Urban form, Transport infrastructure, Land use transport model

\footnotetext{
${ }^{1}$ The authors thank Marianne Fay, Mook Bangalore, Andreas Kopp, Adrien Vogt-Schilb, and the participants to the workshop "green growth modeling", organized at the World Bank in 2013, for their useful comments on a previous version of this article. They also acknowledge support and help from Vincent Viguié on the NEDUM-2D model, and Julie Rozenberg on the global scenarios. All remaining errors are the authors'. The views expressed in this paper are the sole responsibility of the authors. They do not necessarily reflect the views of the World Bank, its executive directors, or the countries they represent.
} 


\section{Introduction}

Urban car transport is a significant source of carbon dioxide $\left(\mathrm{CO}_{2}\right)$ emissions and contributes to climate change, with global impacts on social welfare over centuries. In theory, it would be possible to use Pigouvian taxation (Pigou, 1920) to internalize this negative externality. In this case, a tax is introduced on energy consumption or carbon emissions at a level that corresponds to their social cost. $^{2}$ The implementation of such a unique price of carbon equal to the social cost of carbon would change behaviors in a way that maximizes social welfare. There is a vast literature investigating optimal taxation (Cremer et al., 1998; Sandmo, 1975) and the social cost of carbon (Tol, 2005; Nordhaus, 2008; Interagency Working Group on Social Cost of Carbon, US Government, 2010; Perrissin Fabert et al., 2012).

However, Pigouvian taxation is difficult to implement in practice, and is unlikely to be optimal on its own (Hallegatte et al., 2013). The reasons for this include knowledge spill-overs (Acemoglu et al., 2012), imperfect foresight and the lack of credibility of a long-term carbon price (especially for longlasting infrastructure, see Vogt-Schilb and Hallegatte, 2014), the political obstacle due to the policy impact on existing polluting capital and stranded assets (Rozenberg et al., 2014), and the difficulty in estimating the right level of a Pigouvian tax (e.g., the debate of the social cost of carbon, see Pindyck, 2013).

For these reasons, the debate on climate change policies has been mostly framed in a costeffectiveness approach, in which a target is set in terms of carbon budget or emissions at one point in time (e.g., the $-20 \%$ in emissions by 2020 compared to 1990 levels in the EU climate policy), with policies then designed to reach the target at the lowest possible cost. In this paper, we start from a similar cost-effectiveness approach in which an emission reduction target is introduced with a time horizon that lies between 2020 and 2050.

We investigate the effectiveness of a higher gasoline tax or a carbon price, i.e. their ability to reduce emissions and meet the pre-determined emission-reduction target, and its efficiency, i.e. the cost of reaching the target, in contexts that differ in terms of public transport availability and land-use patterns. We focus on the elasticity of urban transportation emissions with respect to the carbon price, which can vary widely depending on availability of public transport infrastructure. Public transport offers a substitution option away from individual car and is therefore a major determinant of emission elasticity and carbon-pricing effectiveness. Higher elasticity reduces the negative impact of the tax and increases the acceptability of the carbon or gasoline tax, an important consideration in view of the opposition met in recent attempts to introduce such fiscal instruments (Jenkins, 2014; Rozenberg et al., 2014).

This question is highly policy-relevant, as many cities in developing countries are in the process of designing and building their infrastructure network - thus shaping their urban form for the next century and beyond (Lecocq and Shalizi, 2014). It is therefore critical to understand how these shortterm decisions will affect how these cities could implement a carbon price in the future and how effective this price would be in cutting emissions. To investigate this issue, we compare two cities:

\footnotetext{
${ }^{2}$ Carbon emission is hardly the only externality generated by car transport. While road congestion can be experienced closely in many urban regions on a daily basis, other externalities from road transport are as important: local air pollution, noise and accidents have significant economic and social costs, and calls have been made for policy intervention (Bento et al., 2013; IMF, 2013). These other externalities should also be taken into account when designing urban and transport policies.
} 
Paris as it exists in 2010, and a counterfactual Paris in which no public transport infrastructure would have been built. We use a transport - land use model (NEDUM-2D) calibrated for these two scenarios to compare the resulting $\mathrm{CO}_{2}$ emissions and their response to carbon pricing or other gasoline taxes.

We find that both the effectiveness and efficiency of carbon or gasoline taxes are much higher when a dense public transport network is available. In the short to medium term the price elasticity of commuting-related $\mathrm{CO}_{2}$ emissions is about twice as high when public transport exists. In the longer term however, price elasticities tend to converge although they remain higher by about $20 \%$ on average when public transport is available. These results provide a quantified estimate of how much more effective price signals are in changing behaviors when complemented by other instruments such as public transport investments. ${ }^{3}$ This exercise provides estimates of the extent to which fast growing cities in the developing world will be able to curb their future transport emissions, depending on their near-term infrastructure investment decisions.

The remainder of this paper is structured as follows: In Section 2 we decompose commuting related $\mathrm{CO}_{2}$ emissions and express the elasticity of emissions to fuel prices consequentially. In Section 3 we present the main features of the urban model NEDUM-2D that is used to assess emissions on the Paris urban area. Then we outline the method for building the two scenarios: one with public transport as it currently exists, and the other without. Section 4 presents the estimated effects of introducing various carbon or gasoline taxes in the two scenarios. Section 5 compares our results with econometric estimates of car travel or fuel consumption price elasticity, and explores whether our model results can help to explain these results. Section 6 summarizes the findings and concludes.

\section{Fuel price elasticity of $\mathrm{CO}_{2}$ emissions from commuting - The analytical basis}

A useful way of understanding and representing $\mathrm{CO}_{2}$ emissions is to resort to a Kaya type equation (Kaya and Yokobori, 1997; Schipper et al., 2000), which identifies the key drivers of emission dynamics.

Assuming that public transportation is carbon-free ${ }^{4}$, we decompose the aggregate emissions from commuting in Paris in a given year $E_{c}$, as:

$$
E_{c}(p)=P o p *\left(\frac{K M(p)}{P o p}\right) * C A R(p) * E_{C A R}(p)
$$

where Pop denotes the population size, $K M$ is the distance between people's residential and work places, $C A R$ is the fraction of commuting that is done with individual vehicles, and $E_{C A R}$ is the

\footnotetext{
${ }^{3}$ However, optimal taxation is decreasing with the price elasticity of demand (Ramsey, 1927). If a carbon tax is implemented to raise government revenue, not to change behaviors, there is no incentive to implement complementary policies that increase price elasticity.

${ }^{4}$ This assumption is reasonable for metro and trams in Paris, which use low-carbon electricity due to the high ratio of nuclear energy in the French electricity mix. In other countries and when considering buses or electricity produced with fossil fuels, public transport can be a large emitter, especially where they are inefficient and transport few passengers (Kopp et al., 2013). This simplification does not affect the main qualitative conclusions of the paper, however.
} 
average emissions per kilometer of private vehicles. With the exception of $P o p^{5}$, all variables depend on the on the price of gasoline $p$.

The fact that $C A R$ depends on $p$ reflects the possibility of modal shift, i.e. people shifting from individual vehicles to public transportation (or walking or cycling) and vice versa as the relative prices of each transport mode evolve. The fact that $K M$ depends on fuel prices reflects the possibility that people may decide to live closer to their workplace, and that urban forms change with the price of energy (Gusdorf and Hallegatte, 2007a). For instance, urban density can increase to allow more people to live close to their jobs, resulting in higher buildings, smaller dwellings, and higher land fraction used for buildings (e.g. instead of parks). The fact that $E_{C A R}$ depends on the price of fuel reflects the changes in technologies and cars, from the purchase of smaller, more efficient cars (or even two-wheelers) to more radical changes in car technologies (hybrid cars, electric vehicles). ${ }^{6}$ In line with above, the fuel price elasticity $\xi$ can be written as:

$$
\xi=\frac{\Delta E_{c}}{\Delta p} * \frac{p}{E_{C}}=\frac{\Delta C A R}{\Delta p} * \frac{p}{C A R}+\frac{\Delta K M}{\Delta p} * \frac{p}{K M}+\frac{\Delta E_{C A R}}{\Delta p} * \frac{p}{E_{C A R}}
$$

In practice this price elasticity can be influenced through a number of channels, affecting various elements of the above expression:

- Investments (both public and private) can affect $C A R$, i.e. the share of people using private cars for commuting. As public transport infrastructure gets denser, its convenience for users and its efficiency (in terms of decreased transport times) increases (Bertaud, 2002). Investments in public transport infrastructure therefore allow commuters to shift to public transport modes when confronted with a fuel price increase triggered by a carbon or gasoline tax. On the other hand, if the public transport system is inefficient or inexistent, the modal shift will inherently be limited.

- Public policies and regulation can improve cars' fuel (or carbon) efficiency, i.e. the term $E_{C A R}$. This can be affected through the provision of public incentives to purchase lower emitting cars (e.g. the feebate program introduced in France to tax energy-consuming cars and subsidize efficient ones). Stronger regulatory tools such as standards on the fuel efficiency of cars or on the $\mathrm{CO}_{2}$ emissions $/ \mathrm{km}$ can also have significant impacts on the fuel consumption of the fleet of automobiles as has been noted both in the US and in Europe (Anderson et al., 2011). Fuel efficiency can also increase as a result of R\&D investments in the car industry. Some of these investments will be directly triggered by the increase in fuel prices as the automobile industry seeks to maximize profits and thus adapts to new conditions. Other investments will only be initiated if the state provides a certain amount of subsidies. These subsidies can materialize in the form of R\&D subsidies, rebates on corporate taxes, or even as public-private partnerships to promote the use of low-carbon vehicles. Regardless of their form, as subsidy levels vary, the technological progress towards fuel efficient vehicles is also likely to vary, and thus to directly impact on the elasticity of emissions to fuel price variations.

\footnotetext{
${ }^{5}$ We assume that $p$, the price of gasoline does not affect migration between cities and rural-urban localization choices in a significant way.

${ }^{6}$ In this analysis, we treat income levels as exogenous.
} 
- Behaviors and cultural norms can also influence the ability to lower emissions from commuting. The choice of commuting by car rather than by bus is not only a rational decision based on relative costs, but can also be strongly influenced by deeply embedded beliefs. In a large survey in Scotland, Ellaway and al. (2003) for instance find that car transport provides individuals (in particular males) with psychological benefits such as self-esteem, and feelings of autonomy and prestige, which could not be derived from public transport. Even though such beliefs vary strongly across place and time, their prevalence is likely to hinder modal shift and thus the ability to decrease emissions from transport. The average emissions per kilometer of private vehicles can equally depend on behaviors such as driving style: reduced speed decreases fuel consumption.

In addition to these factors, it is also necessary to distinguish between long and short term elasticities, as impacts manifest themselves at different timescales (Vogt-Schilb et al., 2013, 2012):

- The emissions per kilometer traveled in an individual vehicle can change over relatively short timescales, when individuals replace their old car with smaller or more fuel efficient vehicles. This timescale depends on the replacement pace of vehicles - we assume this to be ten years as in Turton and Moura (2008). Over a longer timescale, and assuming that the price of gasoline changes in regions or countries that are large enough to influence marketing choices and R\&D policies of automakers, then the supply of vehicles will also change, allowing for a more radical reduction in $E_{C A R}$ by supplying technologically more advanced vehicles.

- The change in kilometers traveled to commute also involves several timescales. Over short timescales, a small share of individuals will move closer to their workplace, leading to an increase in rents around business districts, and thus a reduction in average dwelling size. This can occur reasonably quickly as apartments can be split without extensive structural work on buildings, and as housing practices can evolve: students may stay with their parents, or apartments may be shared by several individuals. Significant changes in density, however, can only be achieved over the long term, when buildings are extended or replaced. In historical neighborhoods, it may take centuries; in locations with more recent building stock, it may take a few years or decades. ${ }^{7}$

- Modal shift can be instantaneous, as people can decide overnight to take public transportation. However, as explained above, the ability to shift depends on the availability of suitable public transport alternatives, for which public investment plays a critical role in the long term. In this study we do not account for potential congestion effects in public transit that this modal shift could trigger. It is assumed that small investments can be made in order to increase carrying capacities of the existing infrastructure or that service regularity can be increased over a short period of time.

Particularly over long timescales these different mechanisms can take effect, resulting in a larger price elasticity of emissions from commuting. In this paper, we propose to illustrate and quantify this effect for the specific case of Paris, distinguishing between the short and the longer term.

\footnotetext{
${ }^{7}$ See for instance how single-family houses are rapidly replaced by multi-story multi-family buildings in downtown Lima, Peru.
} 


\section{Methodology}

\subsection{The main features of the numerical modeling framework: NEDUM-2D}

NEDUM-2D is a model designed to capture the dynamics of urban systems, and the importance of inertia, i.e. the slow pace at which cities evolve to adapt to new socio-economic conditions (Viguié and Hallegatte 2012). It is based on a model developed in Gusdorf and Hallegatte (2007a, 2007b), Gusdorf et al. (2008). It is a dynamic model which relies on the classical urban economics framework, an economic modeling approach developed in the 1960s (Alonso (1964), Mills (1967), Muth (1969)) and comprehensively described in Fujita (1989). It aims at explaining the spatial distribution of land and of real estate costs, housing surfaces, population densities, and building heights and densities.

NEDUM-2D differs from the model developed in Fujita (1989). First, it introduces dynamics, which enables it to take into account the effect of a global change in income or population. As explained in Gusdorf et al. (2008), urban economics has mostly been used to explore the characteristics of longrun equilibria. However, when population, transport prices, or income vary (sometimes in unpredictable ways), housing infrastructure cannot adapt instantaneously to changing conditions. NEDUM-2D explicitly represents these dynamics and accounts for temporary imbalances between housing supply and demand.

Second, the theoretical model described by Fujita (1989) represents spatial differences solely as a function of the distance to the city center. As the name suggests NEDUM-2D is two dimensional, meaning that it is an urban model which represents urbanization on a map rather than on a single axis. For the Paris urban area, NEDUM-2D uses a grid of $100 \mathrm{~km}^{2}$ with cells of $1 \mathrm{~km}^{2}$. It can therefore account for spatial differences in land use and accessibility at a much finer scale. The model can represent differences between two cells situated at the same distance from the city center such as the amount of land that can be built upon due to geographical and institutional constraints or the proximity to public transport lines.

Three main mechanisms drive the modeling: First, we suppose that households choose their accommodation location and size by making a trade-off between the proximity to the city center (i.e. to the jobs in a mono-centric city) and real estate prices. Second, real estate developers choose to build more or less housing (i.e. larger or smaller buildings) at a specific location, depending on local real estate prices. Third, we suppose that city characteristics do not all evolve and adjust at the same speed. For instance, rents can evolve very quickly, whereas buildings change over a much longer timescale. As can be observed in Paris, construction is also much quicker than building destruction reflecting the existence of important sunk costs in housing structures, thus explaining a certain path dependency and asymmetry in a city's evolution.

With the required data, it is then possible to use these mechanisms to reproduce the internal structure of an actual city. Such an exercise was carried out for the Paris agglomeration (see Viguié and Hallegatte (2012) for the results and a full description of the model), noticeably by introducing realistic transportation networks (both public and private) together with current land-use constraints on the Paris agglomeration. Map 1 below provides an idea of the model's ability to reproduce Paris' urbanized area. More insights on the model's capacity to convincingly simulate the main features of the Paris urban area are provided in Viguié and Hallegatte (2012) and Viguié, Hallegatte and Rozenberg (2014). 

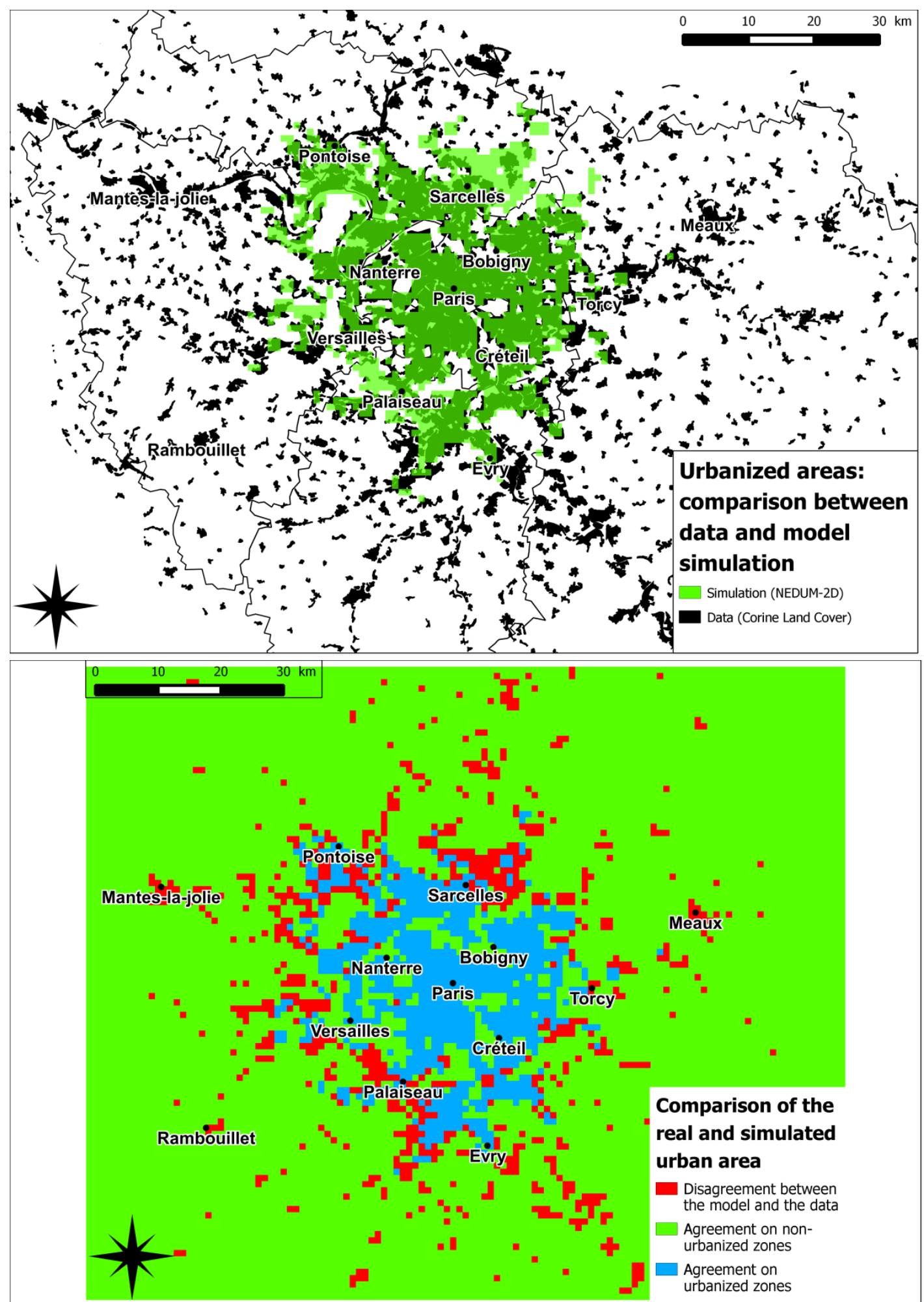

Map 1: Top panel The simulated and real urban area of Paris in 2006. The green shade corresponds to the simulation whilst the black is geographic data (Source: Corine Land Cover (European Union and SOes, 2006)). The dark green shade shows areas where the model accurately predicts urbanization. Light green shows areas where the model inaccurately predicts urbanization. Black stands for areas where the model fails to reproduce urbanization. Finally where the map is white, there is no urbanization and the model agrees with the data. Bottom panel The agreement and disagreement between the data and the model on the urbanized and non-urbanized zones of the Paris urban area in 2006. The green and blue shades show agreement between the model and the data respectively for non-urbanized and urbanized zones. The red shade shows disagreement between the model and the data. 


\subsection{Description of the transport module}

The transportation module of the NEDUM-2D model represents modal choice. For each location in the urban area, citizens choose between walking, public transport and private vehicles, or a combination thereof as a means for commuting. The competition between these modes is organized on the basis of their generalized costs (i.e. the total cost including both the cost of time and the monetary costs incurred during the trip to the city center). It is assumed in this study that modal switch does not affect congestion levels and therefore leaves commuting times unchanged. In order to reflect the heterogeneity of citizens' preferences in terms of transport modes we employ a discrete choice model (De Palma and Thisse, 1987). We follow a common approach in transportation economics by using a multinomial logit model which assigns usage probabilities to each transport mode (see Salon 2009; Washbrook, Haider, and Jaccard 2006). This method ensures that even when one mode is much cheaper than the others, it will not be used by all residents in a location for all trips. The mode share of public transport in the model in 2006 for the Paris urban area (measured as the share of people using public transport) is around $35.5 \%$, so relatively close to the $40 \%$ observed in 2001 (DRIEA, 2005).

For the purposes of our study, the model was enhanced by introducing a mechanism which links average emissions of new cars to the evolution of the price of fuel. The fuel consumption ${ }^{8}$ of new internal combustion engine vehicles decreases with the price of fuel as follows:

$$
\log \left(E_{C A R_{t}}\right)=\log \left(E_{C A R_{t-1}}\right)+\gamma \log \left(\frac{P_{t}}{P_{t-1}}\right)
$$

where $\gamma$ represents the fuel price elasticity of consumption of new vehicles. Building on work conducted by $\mathrm{Li}$ et al. (2009) which examines the effects of gasoline prices on vehicle fleet composition in 20 US cities, we have selected a value of -0.2 for this elasticity. New vehicles are only acquired gradually, depending on both renewal of the existing fleet and new demand. Vehicles are assumed to have a ten year life cycle (Turton and Moura, 2008), such that only a tenth of the fleet is renewed each year. New demand is created due to demographic dynamics, as newcomers may choose to commute by car. Overall, the average fuel consumption of vehicles will decrease as fuel prices increase, but with a certain degree of inertia. This way of representing evolution of fuel efficiency allows capturing rebound effects as commuting decisions are ultimately based on travel prices per $\mathrm{km}$ and not on the price of gasoline. An increase in the fuel efficiency of cars has two opposite effects on $\mathrm{CO}_{2}$ emissions: First it lowers the emissions per km whilst at the same time, by reducing the cost of traveling by car, it tends to increase the amount of traveling leading to an increase in $\mathrm{CO}_{2}$ emissions. The net impact is a decrease in carbon dioxide emissions that is lower than could be expected from fuel efficiency with unchanged behaviors.

\subsection{Application to commuting in the Paris metropolitan region}

In order to investigate the impact of carbon or gasoline taxes on $\mathrm{CO}_{2}$ emissions and mobility, our study relies on projections of the various inputs to the NEDUM-2D model until 2050; in particular the future evolution of transport prices, income, and population. We selected these from one of the scenarios produced by the global energy modeling framework IMACLIM-R (Rozenberg et al., 2010; Waisman et al., 2012), which was used and detailed in a previous study (Viguié et al., 2014). In this

\footnotetext{
${ }^{8}$ As we only consider Internal Combustion Engines (ICE) and not alternative propulsion systems in this paper, we assume that $\mathrm{CO}_{2}$ emissions per kilometer are proportional to the fuel consumption per kilometer.
} 
scenario, the prices of fuel and public transport increase at similar paces reaching respectively $160 \%$ and $145 \%$ of their 2006 levels in 2050 . Average incomes increase at an annual rate of $1.8 \%$, while population in the urban area in 2050 is $18 \%$ larger than in 2006.

The primary aim of this paper is to compare an unconstrained baseline to projections that involve a carbon or gasoline tax, keeping all other inputs unchanged. As a first step, the scenario we chose will enable us to do so for a given evolution pattern of main urban and transport determinants. In a second step, we will investigate the importance of the choice of the baseline scenario by exploring a trajectory in which all inputs (income and population) remain constant up to 2050. This extreme case will enable us to discuss how the fuel price elasticities of $\mathrm{CO}_{2}$ emissions are affected when a city is not growing and the inertia is stronger (see section 4.5).

The exercise presented here consists of simulations of the urban expansion of the Paris agglomeration using NEDUM-2D from 2006 to 2050. A carbon or gasoline tax is then introduced in 2012, and it is assumed that its value increases over time at the same rate as households' mean income. ${ }^{9}$ Various starting values (in 2012) of the carbon or gasoline tax are tested, ranging from 50 to $1000 € / \mathrm{tCO}_{2}$. For simplicity the carbon tax values that are mentioned in the rest of this paper are the starting values in 2012, not the actual values at different points in time. Two series of simulations are conducted: the first considers private vehicles as the only means of transport whilst the second includes the currently existing public transport infrastructure.

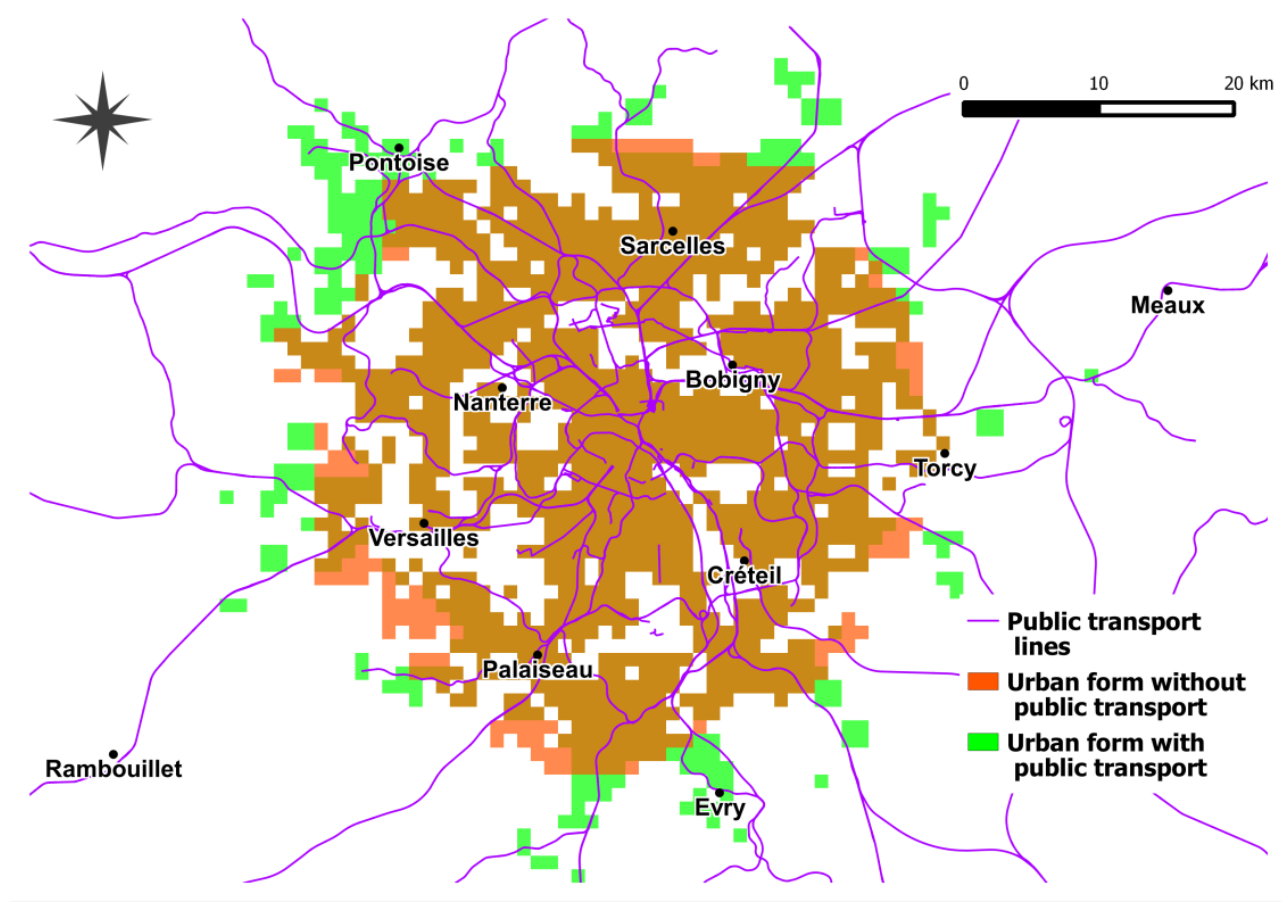

Map 2: The simulated spatial extension of Paris with public transport (green) and without (orange). Where the figure is brown the two maps overlap.

The aim of this paper is then to compare the results achieved in terms of $\mathrm{CO}_{2}$ emissions with or without the city's public transport infrastructure. The counterfactual scenario where public transport

\footnotetext{
${ }^{9}$ The question of recycling carbon revenues, for example by re-investing them in low-carbon forms of transport, although interesting, is beyond the scope of this paper.
} 
does not exist is achieved by limiting the choice of commuters in the transport module to only two modes: cars and walking instead of three possible when the public transport network is available.

Ideally, in an economy managed by a social planner that seeks to maximize social well-being with perfect foresight, the existence of a carbon constraint (or a carbon price) would trigger appropriate regulatory reforms and investments to adapt infrastructure. However, decision-makers can fail to anticipate evolutions of socio-economic conditions such as the future prices of energy carriers, and infrastructure decisions are usually driven by many non-economic constraints. Market and government failures such as the lack of access to credit to finance infrastructure development can impair the development of infrastructure (World Bank, 2012). Moreover, infrastructure is characterized by significant path dependencies, which implies that it cannot adapt rapidly to new constraints and new policies, including climate policies (Guivarch and Hallegatte, 2011; Vogt-Schilb et al., 2012). This in turn provides a rationale for studying the long lasting impacts of infrastructure provision through the use of scenarios in which infrastructure provision is exogenous.

\subsection{Urban forms in the two scenarios}

The two cities that are simulated by NEDUM-2D have different urban forms depending on whether public transport is available (Map 2). Without public transport, the agglomeration is more diskshaped. Conversely, public transport introduction results in slightly more sprawl ${ }^{10}$ as additional urbanization takes place along the public transport lines. Without public transport, average population density is higher by around $7 \%$, but also spatially more evenly distributed.

The cities that emerge from our modeling exercise present different spatial patterns from the start. As a consequence of the inertia that characterizes the evolution of urban systems, the late introduction of a public transport network in the counterfactual scenario would not enable a fast convergence towards the urban form that would emerge if a public transit network existed from the beginning. Not only would it be very costly since roads, buildings and infrastructure would have to be destroyed, but it would also take decades to build, with results materializing at a very slow pace. Indeed, the urban form can only change very slowly, at the rate of infrastructure renewal.

Map 3 shows the spatial differences in population densities in the two scenarios, with and without public transport infrastructure. Without public transport, households have an incentive to locate closer to the city center in order to shorten their commutes. This can be seen from the red and orange shades that appear within the first $15 \mathrm{~km}$ of the city center. Conversely when public transport exists, households tend to locate less homogenously and to settle along the public transport lines to benefit from quick and cheap access to central Paris. As seen in Map 2, public transport loosens the commuting constraint and enables households to move further away from the city center, but only along the public transport lines. The green shade shows that when public transport exists, there is population redeployment towards the outskirts of the urban area, which closely follows the public transport infrastructure.

\footnotetext{
${ }^{10}$ This is because the addition of a transport mode in the model provides an interesting alternative to cars and walking in some locations, and therefore lowers the overall cost of transport. This finding is consistent with related results in the literature (Baum-Snow, 2007; Brueckner, 2005; Viguié and Hallegatte, 2012). Although none of these papers have specifically studied the introduction of public transport they all indicate that lower transport costs will lead to urban spatial expansion.
} 


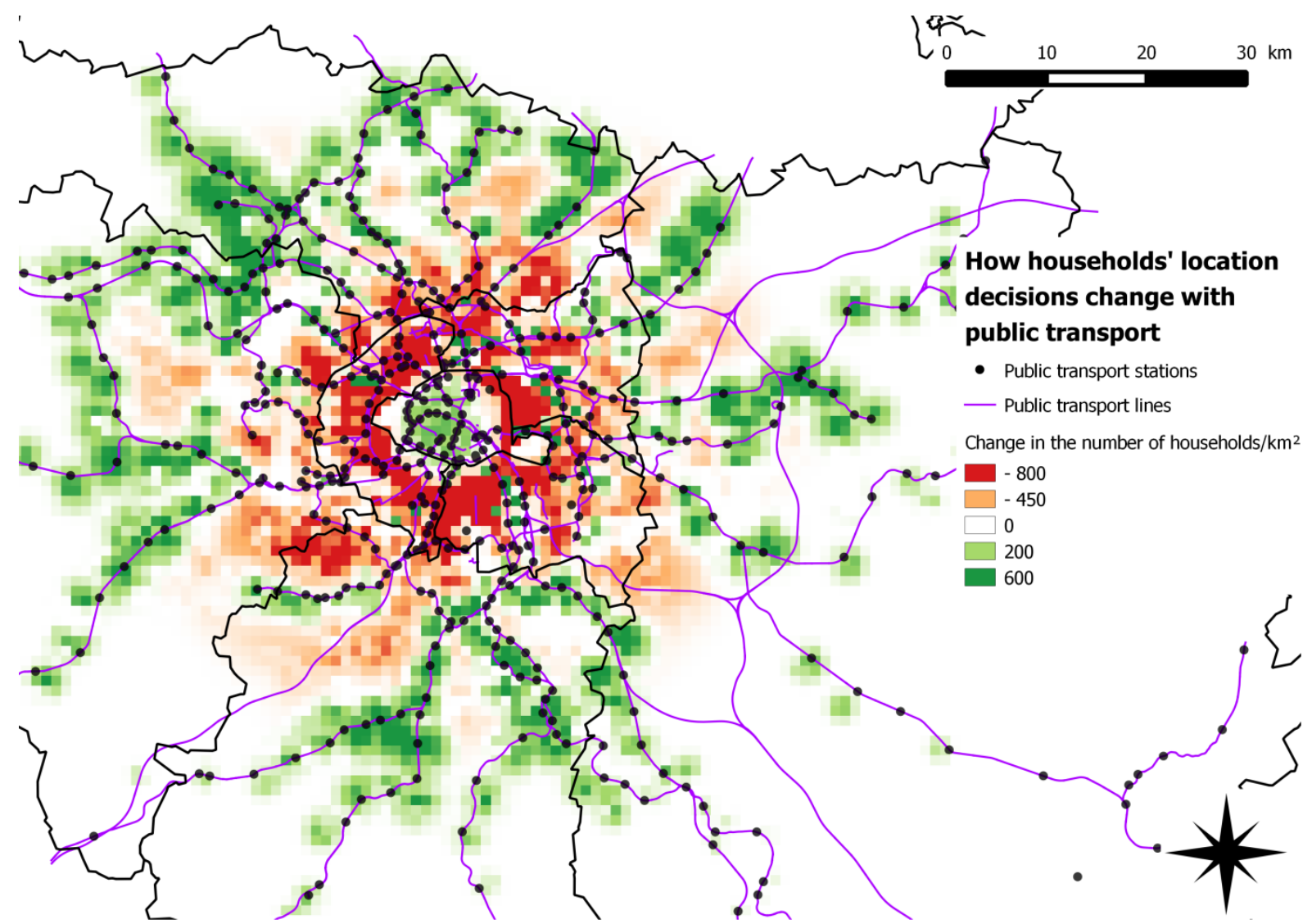

Map 3: Comparison of households' location decisions when public transport exists relative to a counterfactual scenario without public transport

In the absence of public transport, $\mathrm{CO}_{2}$ emissions in Paris are much higher than in the presence of public transport infrastructure. In fact, they are up to $78 \%$ higher in the absence of a carbon tax. This large difference is also based on the assumption that public transport infrastructure is powered by low-carbon electricity, i.e. mainly nuclear power generation ${ }^{11}$. Considering figures for the year 2006 it appears that the model underestimates $\mathrm{CO}_{2}$ emissions from transport. Actual emissions reached $7.8 \mathrm{MtCO}_{2}$ (IAU îdF and Région île de France, 2011) in 2005, whilst NEDUM-2D estimates them to be around $5.6 \mathrm{MtCO}_{2}$. However, it is difficult to compare these figures as the model does not capture transport related emissions for other purposes than commuting. Nevertheless, the overall order of magnitude appears correct.

\section{Introducing a carbon tax}

\subsection{The short and medium term impact of a carbon tax}

We examine the impacts in both scenarios over time based on the hypothetical introduction of carbon or gasoline taxes in 2012. Figure 1 provides a graphic illustration of simulated commutingrelated $\mathrm{CO}_{2}$ emissions for carbon or gasoline tax values ranging from 0 (i.e. no tax) to $200 € / \mathrm{tCO}_{2}$ in 2020. These results confirm that increasing carbon or gasoline taxes are indeed able to reduce $\mathrm{CO}_{2}$ emissions, which is consistent with other theoretical and empirical results (see for example Sterner (2007)).

\footnotetext{
${ }^{11}$ In 2012, 75.6\% of French electricity was produced through nuclear power (IEA, Energy Statistics Database).
} 
The impact of carbon taxes on $\mathrm{CO} 2$ emissions levels in the Paris urban area in 2020

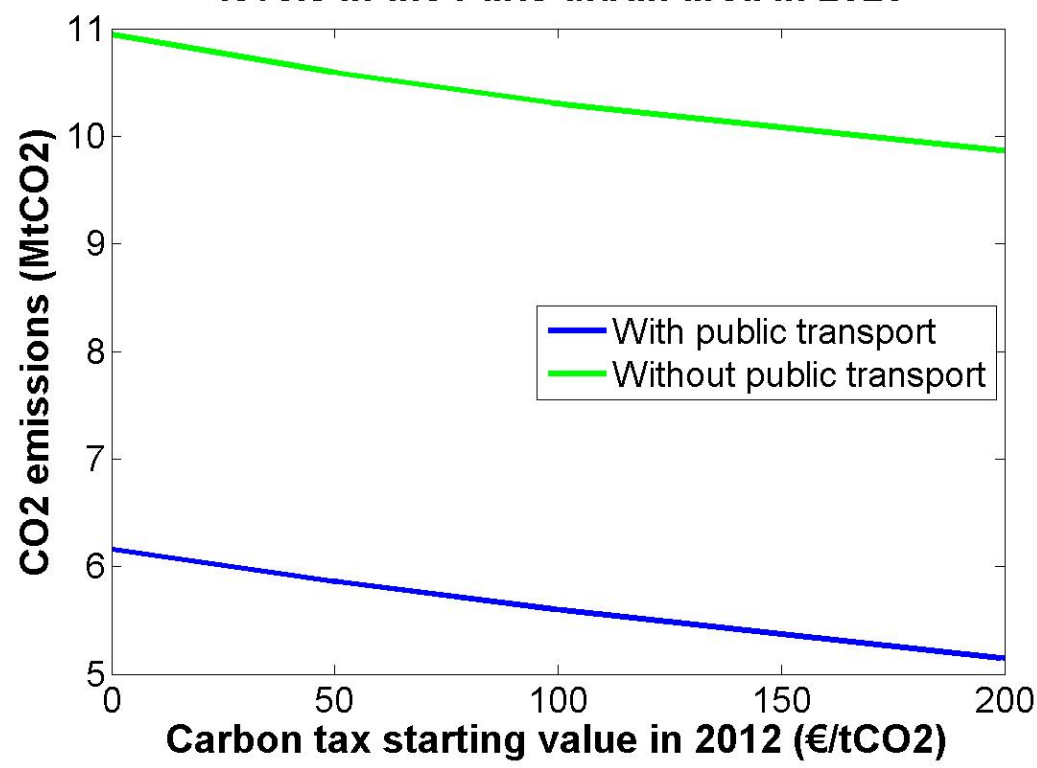

Figure 1 : Commuting-related emission levels for an increasing carbon tax, with and without public transport in 2014

Figure 2 presents the evolution of emissions in relative terms, as a function of tax values in 2020 (emission levels for each tax value divided by the emission level without tax), to demonstrate the effectiveness of $\mathrm{CO}_{2}$ taxes in delivering emission reductions (with and without public transport in place).

The relative impact of carbon taxes on $\mathrm{CO} 2$ emissions in the Paris urban area in 2020

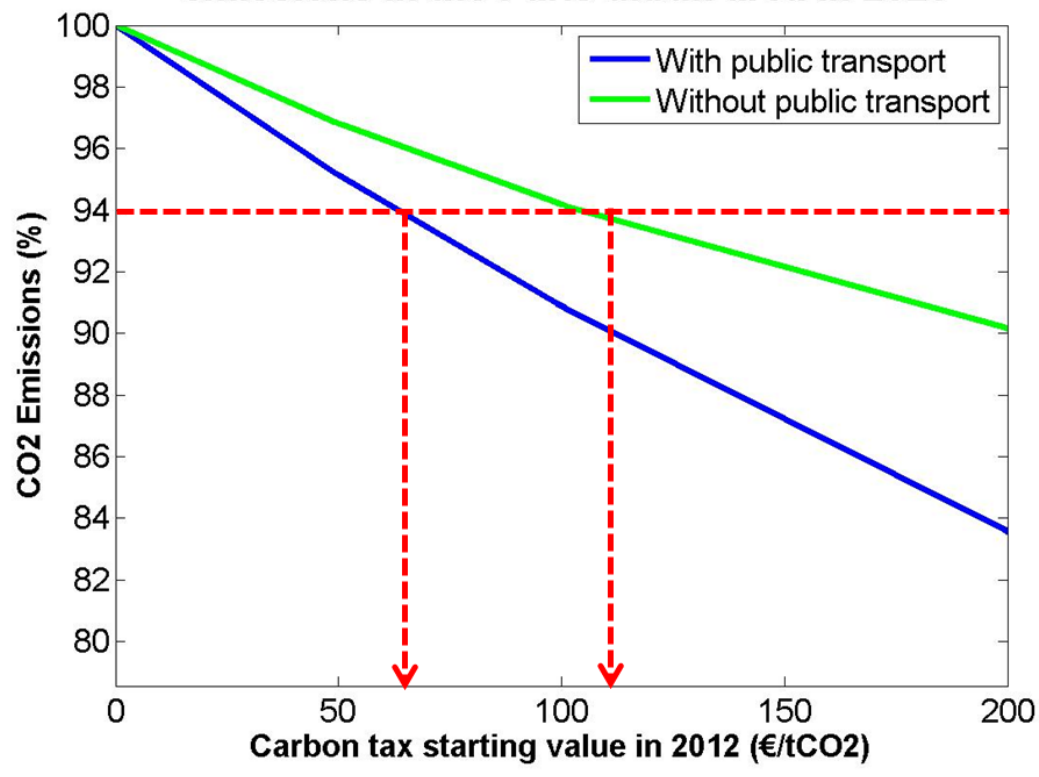

Figure 2 : The relative impact of carbon taxes on commuting-related emission levels in 2020 for scenarios with and without public transport. When the horizontal red dashed line crosses the blue and green curves we can read on the $\mathrm{x}$ axis the carbon tax starting values that must be implemented in 2012 to achieve a $6 \%$ reduction in $\mathrm{CO}_{2}$ emissions ( $65 € / \mathrm{tCO}_{2}$ and $115 € / \mathrm{tCO}_{2}$ respectively with and without public transport). 
It appears that carbon or gasoline taxes are more effective in curbing emissions that stem from transport when an alternative to fossil fuel intensive cars (such as public transport) exists: a $200 € / \mathrm{tCO}_{2}$ carbon tax results in $16 \%$ lower emissions (relative to a situation with no tax) with public transport, compared to a little less than $10 \%$ without (Figure 2). The ratio between the two is 1.6, i.e a $200 € / \mathrm{tCO}_{2}$ carbon tax is greater than $60 \%$ more effective in the medium run when modal shift is possible. In the short run (i.e. until 2014), a $200 € / \mathrm{tCO}_{2}$ carbon tax is 2.3 times more efficient in the presence of public transport than without $\left(14 \% \mathrm{CO}_{2}\right.$ emissions reduction with public transport compared to $6 \%$ without).

Another way of looking at Figure 2 is to consider the carbon or gasoline taxes required to achieve a given abatement objective. In the absence of public transportation, achieving a $6 \%$ decrease in $\mathrm{CO}_{2}$ emissions would require almost double the carbon tax compared to the scenario in which public transport exists $\left(115 € / \mathrm{tCO}_{2}\right.$ instead of $\left.65 € / \mathrm{tCO}_{2}\right)$. Thus, a carbon or gasoline tax is more efficient in the presence of public transport.

Overall, it must be noted that even with public transport, carbon taxes need to be high in order to achieve a relatively small abatement target. For instance, in the scenario with public transport, achieving a $6 \%$ reduction in $\mathrm{CO} 2$ emissions requires a carbon tax of $65 € / \mathrm{tCO}_{2}$ over eight years. By comparison, the carbon tax which was debated in France in 2008 was only $17 € / \mathrm{tCO}_{2}$. Yet this bill failed in part because the financial burden on commuters living far from public transport was considered to be too high.

Part of this inefficiency of the carbon tax in reorienting behaviors towards more sustainable location and commuting decisions can be explained by the importance of the time cost component compared to the monetary component of commuting costs. Indeed Viguié, Hallegatte and Rozenberg (2014) show that the cost of time in 2010 represents up to $90 \%$ of the generalized costs of transport in the Paris urban area (and 95\% in 2050). Therefore even a strong increase in fuel prices will only marginally affect generalized costs and travel behavior. ${ }^{12}$

\subsection{The long-run impact of carbon or gasoline taxes}

Figure 3 compares emission reductions in 2050 with and without public transport for various carbon tax values. The red dashed lines show that to achieve a $15 \%$ reduction in $\mathrm{CO}_{2}$ emissions, the tax should be approximately $120 € / \mathrm{tCO}_{2}$ with public transport, and $140 € / \mathrm{tCO}_{2}$ without. The efficiency of carbon taxes remains higher for all tax levels if public transport exists ${ }^{13}$. However, in the long run (2050), the impacts of carbon or gasoline taxes on $\mathrm{CO}_{2}$ emissions are much closer between a situation with and without public transport than in the short and medium run.

\footnotetext{
${ }^{12}$ In the presence of Pigouvian taxation, in which a carbon tax is introduced at a level equal to the "social cost of carbon", this low elasticity would translate into small emission reductions in the individual transport sector. In a cost-effectiveness framework, in which we start from a target in terms of emission reduction, the required emission reductions depend on how ambitious the target is. Importantly, considering the timescale of emission reduction in this sector, the need to reduce emissions in the transport sector will be affected by the long-term targets (2050 and below), not only short-term objectives. See an illustration for Brazil in (Vogt-Schilb et al., 2014).

${ }^{13}$ It should equally be noted that the absolute level of emissions remains much higher in a situation without public transport.
} 


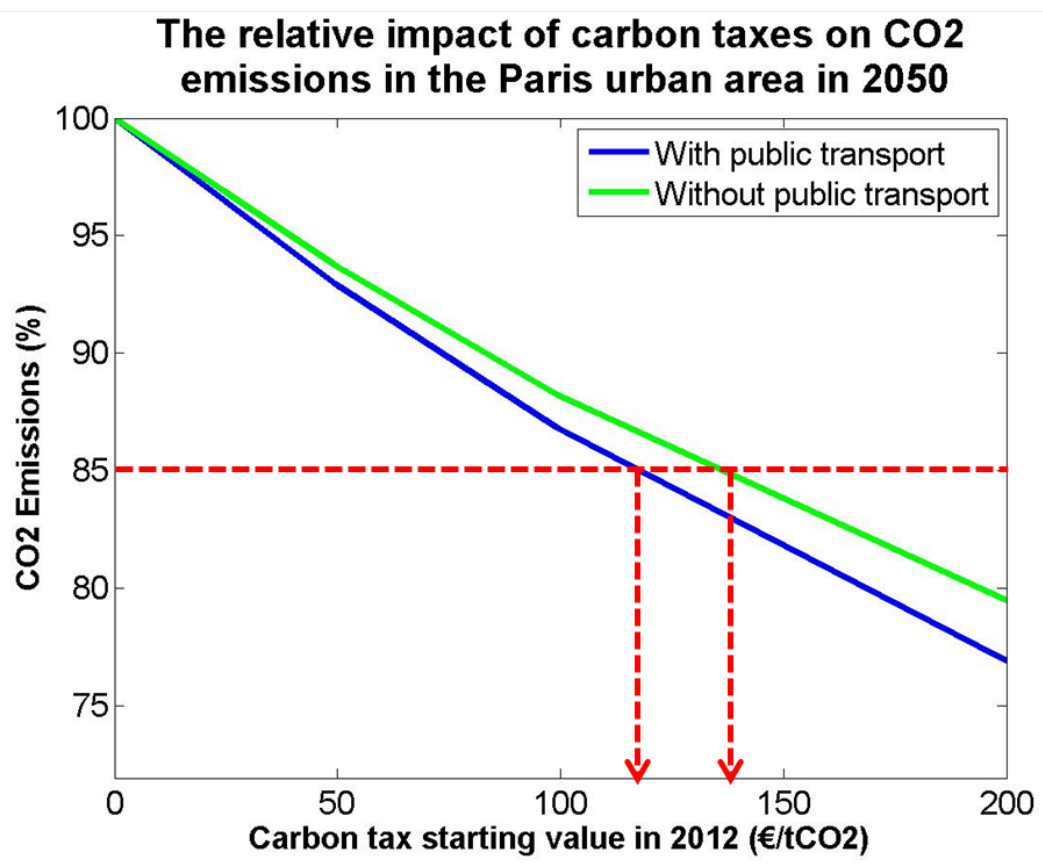

Figure 3: The impact of carbon taxes on commuting-related emission levels in 2050 for scenarios with and without public transport. When the horizontal red dashed line crosses the blue and green curves we can read on the $\mathrm{x}$-axis the carbon tax starting values that must be implemented in 2012 to achieve a $15 \%$ reduction in $\mathrm{CO}_{2}$ emissions $\left(120 € / \mathrm{tCO}_{2}\right.$ and 140 $€ / \mathrm{CO}_{2}$ respectively with and without public transport.

There is a straightforward explanation: without public transport, households can only mitigate the adverse effects of a carbon or gasoline tax by moving. Due to the inertia that characterizes construction and relocation decisions, such a strategy cannot have large impacts in the short term. Indeed, with fixed housing supply, the carbon price incentives to live close to employment centers mostly translate into higher rents that will cancel most of the incentives. Only when these higher rents translate into higher-density construction and larger housing supply near to employment centers can population relocation play a significant role in emission reduction.

\subsection{The roles of modal split, fuel efficiency and urban reconfiguration}

This section presents evidence for the different channels through which $\mathrm{CO}_{2}$ emissions are reduced by carbon pricing. We find that in the presence of a public transport system, the share of public transport usage is increasing over time. When no carbon or gasoline tax is introduced the share of public transport is estimated to increase from 36\% (2014) to 38\% (2050) due to a moderate relative decrease in transit prices. When a relatively high carbon or gasoline tax is introduced (equivalent to $200 € /$ tCO2 in 2012), the modal share of public transport increases to $40 \%$ in 2014 , and up to $41 \%$ in 2050. The rapid increase in transit usage reflects the fact that mode choice can evolve virtually overnight. ${ }^{14}$ However, once the mode switch potential is exploited, the share of public transport is virtually constant throughout the whole simulation period. Generally, the share of public transport increases over time and this behavior is stronger for higher levels of the carbon or gasoline tax. However, while the overall modal transfer towards public transport is found to be significant, it is still relatively moderate in size.

\footnotetext{
${ }^{14}$ The reader should be reminded that in this study we do not account for potential congestion effects in public transit. It is assumed that small investments can be made in order to increase carrying capacities of the existing infrastructure or that service regularity can be increased over a short period of time.
} 
Figure 4 indicates, for a $200 € / \mathrm{tCO}_{2}$ tax, to what extent modal split and other channels contribute to the decrease in emissions.

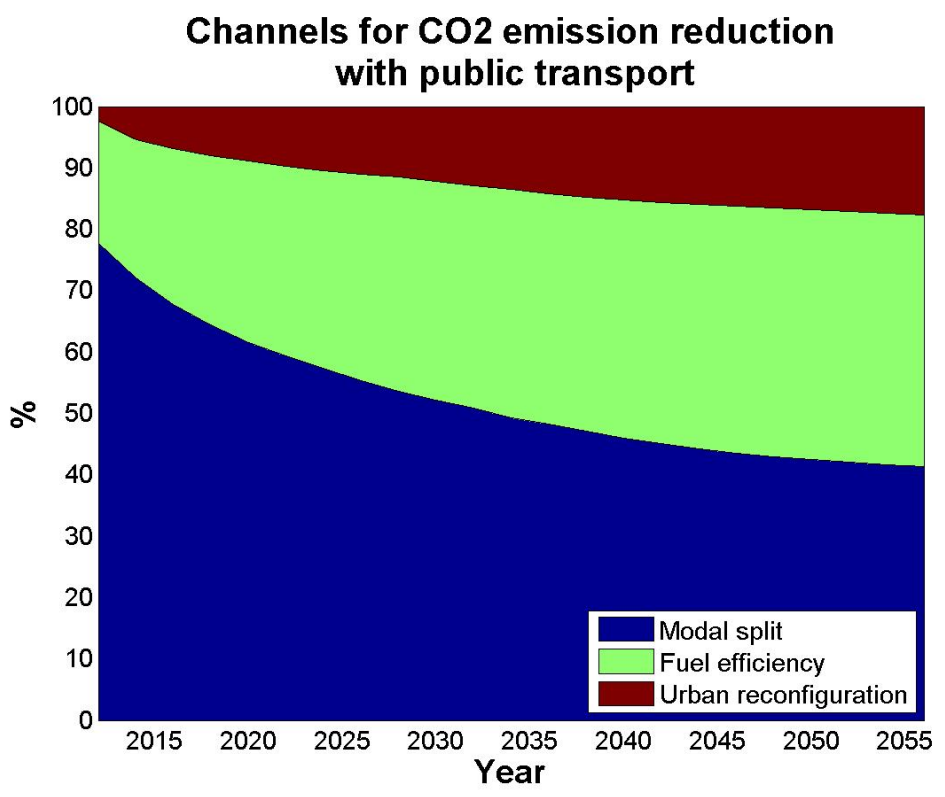

Figure 4: Contributions of different channels towards a $\mathrm{CO}_{2}$ emission decrease with a $200 € / \mathrm{tCO}_{2}$ tax with public transport.

Figure 4 suggests that, when public transport is available, modal split explains the largest share of emission reductions in the short term. Over a longer time span, the importance of urban reconfiguration and fuel efficiency grows, constituting together around $60 \%$ of the overall effect in 2055. Households will gradually relocate inside the urban area towards zones that allow shorter commuting distances. This inertia also characterizes the rate at which the vehicle fleet can be renewed. Therefore, switching to public transit is the most viable option in the short run if fuel prices increase.

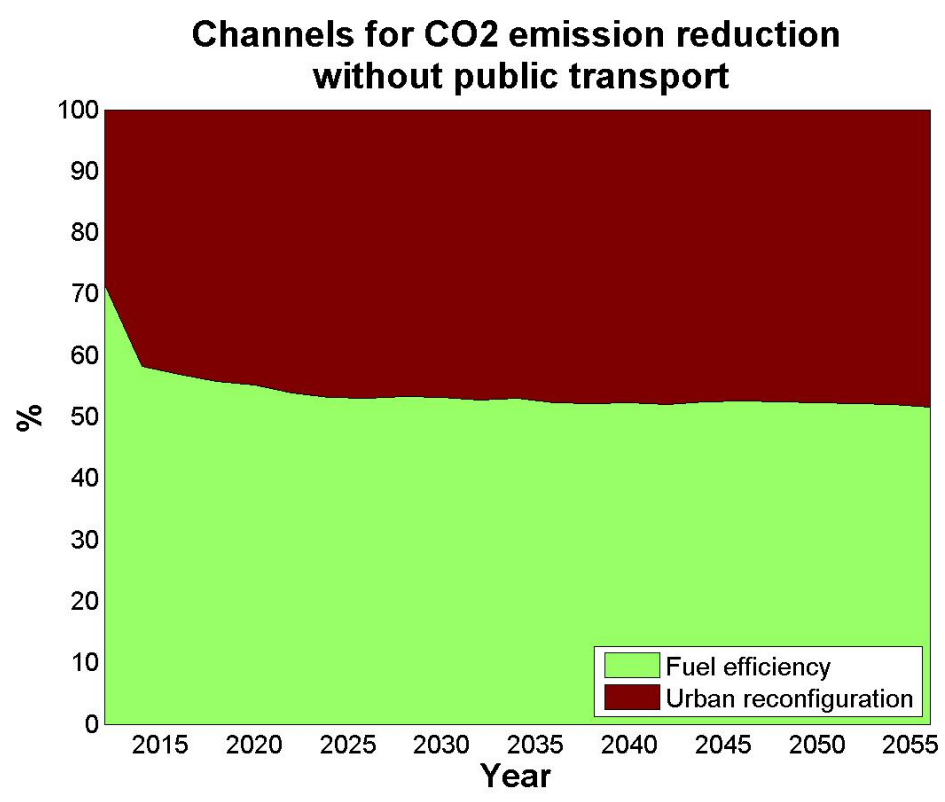

Figure 5: Contributions of different channels towards a $\mathrm{CO}_{2}$ emission decrease with a $200 € / \mathrm{tCO}_{2}$ tax without public transport. 
In the scenario without public transport, both the progress in the development of fuel efficient vehicles and in urban reconfiguration are characterized by high inertia (Figure 5 ). They nearly evolve in parallel throughout the entire time frame, although in the very short term fuel efficiency prevails. Taken together, these figures show that when no immediate alternatives exist (e.g. switching to public transport), a very costly abatement option such as relocation is resorted to. These illustrations thus also highlight the high cost of reducing $\mathrm{CO}_{2}$ emissions from commuting when no public transport exists.

\subsection{Price elasticities}

We find that decarbonizing commuting (in relative terms) is more efficient (i.e. cheaper) when public transport systems are available. The estimated fuel price elasticities of $\mathrm{CO}_{2}$ emissions are presented in Table 1 for five different levels of carbon or gasoline taxes, both in the presence and absence of a public transit system. For each respective level of carbon or gasoline tax, the elasticities expressed in absolute terms are higher with public transport than without. This observation holds for any chosen level of carbon or gasoline tax, and for any considered time horizon. The elasticities with public transport are roughly twice as high as those without public transport in the short to medium term.

\begin{tabular}{|c|c|c|c|c|c|c|c|c|c|c|c|}
\hline & & \multicolumn{2}{|c|}{$50 € / \mathrm{tCO}$} & \multicolumn{2}{|c|}{$100 € / \mathrm{tCO} 2$} & \multicolumn{2}{|c|}{$200 € / \mathrm{tCO} 2$} & \multicolumn{2}{|c|}{$500 € / \mathrm{tCO} 2$} & \multicolumn{2}{|c|}{$1000 € / \mathrm{tCO} 2$} \\
\hline & & $\begin{array}{c}\text { With Public } \\
\text { transport }\end{array}$ & $\begin{array}{c}\text { Without } \\
\text { Public } \\
\text { transport }\end{array}$ & $\begin{array}{c}\text { With Public } \\
\text { transport }\end{array}$ & $\begin{array}{c}\text { Without } \\
\text { Public } \\
\text { transport }\end{array}$ & $\begin{array}{c}\text { With Public } \\
\text { transport }\end{array}$ & $\begin{array}{c}\text { Without } \\
\text { Public } \\
\text { transport }\end{array}$ & $\begin{array}{c}\text { With Public } \\
\text { transport }\end{array}$ & $\begin{array}{c}\text { Without } \\
\text { Public } \\
\text { transport }\end{array}$ & $\begin{array}{c}\text { With Public } \\
\text { transport }\end{array}$ & $\begin{array}{c}\text { Without } \\
\text { Public } \\
\text { transport }\end{array}$ \\
\hline \multirow{3}{*}{$\begin{array}{l}\text { Emissions' } \\
\text { fuel price } \\
\text { elasticity }\end{array}$} & $\begin{array}{c}\text { Short term } \\
\text { (2014) }\end{array}$ & $-0,44$ & $-0,20$ & $-0,45$ & $-0,20$ & $-0,47$ & $-0,20$ & $-0,52$ & $-0,20$ & $-0,60$ & $-0,21$ \\
\hline & \begin{tabular}{|c|} 
Medium \\
term (2020)
\end{tabular} & $-0,50$ & $-0,32$ & $-0,50$ & $-0,31$ & $-0,51$ & $-0,30$ & $-0,55$ & $-0,27$ & $-0,62$ & $-0,27$ \\
\hline & $\begin{array}{l}\text { Long term } \\
\text { (2050) }\end{array}$ & $-0,52$ & $-0,46$ & $-0,53$ & $-0,47$ & $-0,55$ & $-0,48$ & $-0,57$ & $-0,45$ & $-0,62$ & $-0,42$ \\
\hline
\end{tabular}

Table 1: Fuel price elasticities of emissions depending on the level of carbon tax and the presence or absence of a public transit system.

Furthermore, these elasticities also increase from the short to the long term (in absolute terms) from $[-0.44--0.60]$ to $[-0.52--0.62]$ with public transport and from -0.2 to $[-0.42--0.48]$ without. In the short run individual responses to fuel price increases are mainly limited to shifting to different means of transport (e.g. cycling, or public transport, if available) and putting more emphasis on fuel efficient driving. However, in the long run people have further options, e.g. by relocating closer to the workplace, or by adjusting the fleet of vehicles to the new price conditions. Since such long run options depend less on public transport, elasticities tend to not only increase, but also converge over time in both scenarios and for all considered levels of carbon tax. Elasticities in the long run are in the [-0.52 - -0.62] range with public transport and [-0.42- -0.48] without. On average over the five levels of carbon taxes, long run elasticities are higher (in absolute terms) by $20 \%$ with public transport.

We also find that the elasticities evolve with the level of tax: In the scenario with public transport, the elasticities strictly increase with every rise in the carbon tax across all three time horizons. However, in the scenario without public transport, short term elasticities are found to remain virtually constant for all considered carbon tax levels, as people have limited options to switch to alternative forms of transport. In the long term, the elasticity increases up to a certain level of carbon $\operatorname{tax}\left(200 € / \mathrm{tCO}_{2}\right)$ and then decreases.

One reason is the presence of non-linear construction costs. Indeed, the lack of public transportation leaves people with relocation as one of the main response options. However, moving closer to jobs 
will be increasingly costly, as high population density entails high construction costs. Real estate developers optimize building types and heights as a function of the expected revenues and costs. Higher rents justify higher buildings, but the non-linearity in construction costs means that the gain in density is lower when density is already high. These "decreasing returns from density" mean that, above a certain level, increasing density becomes a very expensive way of reducing transportation costs.

\subsection{Role of the baseline scenario}

In order to control for the role of population and income growth, we also conducted a set of simulations based on the hypothesis that income and population remain constant between 2006 and 2050. This scenario yields less favorable results in terms of the capacity to abate emissions.

Indeed, a growing city has many new buildings constructed every year. These new buildings can be designed to take into account the incentives created by the carbon price, i.e. at higher density close to employment centers and lower density at the outskirts. A city that is growing over time can therefore accommodate changes in relative prices through new construction, while a stagnating city needs to destroy and rebuild, a process that is slower and much more expensive.

\begin{tabular}{|c|c|c|c|c|c|c|c|c|c|c|}
\hline \multirow[b]{2}{*}{$\begin{array}{l}\text { Long term elasticities } \\
\qquad(2050)\end{array}$} & \multicolumn{2}{|c|}{$50 € / \mathrm{tCO} 2$} & \multicolumn{2}{|c|}{$100 € / \mathrm{tCO} 2$} & \multicolumn{2}{|c|}{$200 € / \mathrm{tCO} 2$} & \multicolumn{2}{|c|}{$500 € / \mathrm{tCO} 2$} & \multicolumn{2}{|c|}{$1000 € / \mathrm{tCO} 2$} \\
\hline & $\mid \begin{array}{c}\text { With Public } \\
\text { transport }\end{array}$ & $\begin{array}{c}\text { Without } \\
\text { Public } \\
\text { transport }\end{array}$ & 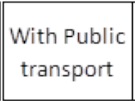 & $\begin{array}{c}\text { Without } \\
\text { Public } \\
\text { transport }\end{array}$ & $\mid \begin{array}{c}\text { With Public } \\
\text { transport }\end{array}$ & $\begin{array}{c}\text { Without } \\
\text { Public } \\
\text { transport }\end{array}$ & $\begin{array}{c}\text { With Public } \\
\text { transport }\end{array}$ & $\begin{array}{c}\text { Without } \\
\text { Public } \\
\text { transport }\end{array}$ & $\begin{array}{c}\text { With Public } \\
\text { transport }\end{array}$ & $\begin{array}{c}\text { Without } \\
\text { Public } \\
\text { transport }\end{array}$ \\
\hline Initial baseline scenario & $-0,52$ & $-0,46$ & $-0,53$ & $-0,47$ & $-0,55$ & $-0,48$ & $-0,57$ & $-0,45$ & $-0,62$ & $-0,42$ \\
\hline $\begin{array}{l}\text { Baseline with constant } \\
\text { population and income }\end{array}$ & $-0,55$ & $-0,37$ & $-0,55$ & $-0,37$ & $-0,55$ & $-0,36$ & $-0,57$ & $-0,36$ & $-0,60$ & $-0,36$ \\
\hline
\end{tabular}

Table 2: Comparison of long term emissions' fuel price elasticities depending on the chosen baseline.

It can be seen from Table 2 that the long term elasticities with public transport remain close to those presented before. Without public transport however, the no-growth assumption very much affects the capacity to decrease emissions. This should not come as a surprise, as the ability to reduce $\mathrm{CO}_{2}$ emissions depends heavily on the capacity to relocate within the urban area. As relocation is more difficult when an urban area is not growing and building, the elasticities are much lower. In the shortrun (not shown here), the elasticities are similar in the two scenarios whether public transport infrastructure is available or not. The changes in population and income relative to the initial baseline scenario are very marginal by 2014 . This explains why, unlike for the long-run, there is little difference in the elasticities in the absence of public transport in the short-run between the two socio-economic scenarios.

Table 2 demonstrates the importance of the choice of the baseline. The capacity to mitigate GHG emissions depends on the reference socio-economic scenarios, including demographic, technological, and economic changes.

\section{Comparing results from the model vs. econometric analysis}

To the best of our knowledge the only other modeling exercise aimed at exploring the price elasticity of fuel consumption from urban traveling is a study by Anas and Hiramatsu (2012) for the city of Chicago, which uses the RELU-TRAN2 model (an extension of the RELU-TRAN model described in (Anas and Liu, 2007)). They find a much lower elasticity of -0.081 . While the reason for this difference 
is not obvious, the share of this elasticity which can be attributed to modal shift in the long run is $43 \%$; i.e. quite similar to our own estimates (see Figure 4).

To see our results in context, it is useful to consider the substantial body of literature analyzing the price elasticity of fuel consumption and road transport based on econometric techniques. Graham and Glaister (2002) offer a comprehensive survey of this literature, based on hundreds of studies on income and price elasticities of fuel consumption. Their survey indicates that throughout the literature price elasticity estimates are surprisingly consistent, with short-term elasticities (up to one year in their definition) mostly falling within a -0.2 to -0.3 range and long-term elasticities falling between -0.6 and -0.8 . These results are in line with other surveys by Goodwin (1992), Dahl (1995), Goodwin et al. (2004), and Kopp et al. (2013).

In a later meta-analysis, Graham and Glaister (2004) conclude that the price elasticity for car travel demand is -0.16 in the short-run and -0.26 in the long-run - i.e. significantly lower than their elasticity estimates for the demand for fuel. In the same order of magnitude, Goodwin et al. (2004) find corresponding elasticities of -0.10 in the short-run and -0.29 in the long-run. In this context, Goodwin et al. (2004) note that consistently throughout the literature price elasticities for fuel consumption are found to be larger than road traffic elasticities by a factor 1.5 to 2 . They suggest that this is due to a more efficient use of fuel in response to a fuel price increase, i.e. individuals would still embark on the same journey by car as before the price increase, but commit to more fuelconserving driving, and switch to more fuel-efficient vehicles. These results are fully consistent with Figure 5 , which indicates that, in the absence of modal shift, around $50 \%$ of emission reductions can be expected from urban reconfiguration (and modal shift when available) and 50\% from more efficient vehicles.

\begin{tabular}{lcccc}
\hline & \multicolumn{2}{c}{ Fuel consumption } & \multicolumn{2}{c}{ Car travel } \\
\hline & $\begin{array}{c}\text { Goodwin et al. } \\
(2004)\end{array}$ & $\begin{array}{c}\text { Graham and Glaister } \\
(2004)\end{array}$ & $\begin{array}{c}\text { Goodwin et al. } \\
(2004)\end{array}$ & $\begin{array}{c}\text { Graham and Glaister } \\
(2004)\end{array}$ \\
\hline Short term & -0.25 & -0.2 to -0.3 & -0.10 & -0.16 \\
Long term & -0.64 & -0.6 to -0.8 & -0.29 & -0.26 \\
\hline
\end{tabular}

Table 3: Short- and long-term elasticity estimates for fuel and car travel demand, based on literature surveys by Graham and Glaister (2004) and Goodwin et al. (2004).

Regarding the difference between short and long-term effects, Jong and Gunn's (2001) results for Europe are also consistent with our findings, as they find that short-term effects were mainly limited to shifts in the mode of transport, while long-term effects also included shifts in the choice of destination and travel frequency, as well as relocation of population and economic activities.

Overall the qualitative nature of our results and their relationship and proportions across different timescales are consistent with the evidence from the literature. In terms of the numerical magnitude of elasticities in the literature, we note that our results in the presence of public transport suggest higher elasticities than presented in Table 3. However, it is important to note that these results cannot be compared directly for various reasons: Considering commuting rather than general transport, implies that 'not traveling' is not an option as people still need to access their workplaces in order to earn their income. In the face of a fuel price increase one would expect that leisure trips, which are not indispensable, would be less frequent. If this were the case we would expect the price 
elasticities of fuel consumption for all travel purposes obtained through econometric methods to be higher in absolute value than our results. On the other hand, leisure trips tend to rely more on private vehicles or even air travel, because low emitting public transportation is a very imperfect substitute outside dense areas and for distant destinations. The city-based approach of our study means that average travel distances are shorter than in country based studies, thus possibly opening travel options such walking, cycling or public transit. This second effect would tend to make fuel price elasticities for commuting trips higher than for all trips.

Moreover, differences in the income level of countries or cities may complicate the comparison of transport elasticities. It has been found that historical price and income elasticities for both the demand for transport fuels and the demand for road transport have been decreasing (see Graham \& Glaister (2004), for a comprehensive literature survey). Fouquet (2012) analyses income and price elasticities for transport demand in the UK, and shows that the price elasticity for transport demand has decreased from -1.5 in 1850 to -0.6 in 2010. He suggests that the reason for this decrease is due to both technological progress and associated reductions in transportation costs, as well as rising income. This observation is confirmed by Graham and Glaister (2004), who also note declining price elasticities throughout the past decades and suggest a negative relationship between price elasticities and real income. This implies that the standard of living can play a role in determining the demand for road transport, and provides a rationale for high price elasticities in developing countries. Hughes, Knittel and Sperling (2008) focusing on the US also study whether the short-run price elasticities of fuel consumption for automobiles have changed since the 1990 as a result of increasing incomes, introduction of fuel consumption standards, and changing land-use patterns. They provide evidence of decreasing price elasticities of gasoline demand. However, they show that the decreasing responsiveness of consumers to gasoline prices cannot be attributed to income growth. They argue that the shift in price elasticities is likely to reflect changes in land-use such as high suburban development and lower accessibility to transit infrastructure. Our results tend to support their analysis.

In this context, a relatively small body of literature looks at city-level elasticities, and illustrates just how much elasticities can differ across cities, emphasizing that city-specific characteristics (such as the availability and efficiency of a public transportation system) play a significant role. Nowak and Savage (2013) for instance estimate cross-elasticities for fuel prices and public transport use for the city of Chicago. They find that for gasoline prices above US\$3 per gallon, the elasticity for rail transport increases to $0.12-0.14$ (from 0.05 for prices below US\$3). For gasoline prices above US\$4, elasticities increase further to $0.28-0.38$. Zhang (2004) estimates the travel cost elasticity for car travel to be -0.14 in Boston, but -0.24 in Hong Kong SAR, China. For New York City, Salon (2009) focuses on commuting in particular and analyzes determinants for commute mode using a discrete choice model. She finds a price elasticity for car commute of -0.33 for the whole of New York City, while estimates vary across different locations within New York: the elasticity is -0.23 for Staten Island and -0.79 for Manhattan which has the highest access to public transport in the urban area. In comparison, the two scenarios in our study can be interpreted to represent two different cities - one with a public transportation system and one without. The significant difference between our results for the two scenarios underscores, in line with the literature, that city-specific characteristics play a critical role in determining the elasticity. 


\section{Concluding remarks}

This paper investigates the impact of path dependencies on the ability to reduce urban commuting $\mathrm{CO}_{2}$ emissions with a carbon or gasoline tax. Due to imperfect decision-making and long planning and construction timescales of new infrastructure, investments in public transport are not always optimal, especially after changes in relative prices (e.g., due to carbon pricing). As a consequence, the provision of public transport does not adapt automatically and instantly to new socio-economic conditions. Exogenous scenarios that describe different patterns of public transport provision are therefore important for assessing the effectiveness and efficiency of price instruments.

We use two simplified and highly contrasted urban scenarios using the NEDUM-2D model. The first scenario looks at the Paris urban agglomeration, assuming that public transport service will remain equal to its 2012 level up until 2050. The second scenario investigates a counterfactual situation in which Paris would have developed without public transport infrastructure. These two scenarios are useful benchmarks to inform decision-makers in fast-growing cities, where decisions regarding public transport infrastructure are currently being made and will affect urban forms for decades and beyond. While the complete absence of public transport constitutes an extreme and hypothetical case, it is useful nevertheless for assessing the extent to which public transport impacts on the efficiency of price instruments to curb gasoline consumption and GHG emissions.

Our results show that public transport choices have a strong influence on the price elasticity of energy consumption and carbon emissions from urban individual transport. They provide an explanation for the varying responsiveness to price signals of different transport modes across time and space, as flagged in Kopp et al. (2013). For instance, the model supports and could help quantify one of the hypotheses made in Hughes et al (2008): They note a decrease in transport price responsiveness in the US between the 1970s and the 2000s, and suspect that the increase in suburban development has made households more dependent on private vehicles and less able to respond to gasoline price changes.

The analysis can also provide scenario-based (e.g., with or without public investment in public transport) elasticity values that can be employed in CGE models, which are used to assess the cost of climate policies. Indeed CGE models usually rely on fixed price elasticities, which are independent of the stock of infrastructure. Our analysis shows that when public transport networks are insufficient or missing, these average elasticities can lead to an overestimation of the capacity to mitigate $\mathrm{CO}_{2}$ emissions or decrease fuel usage from transport. This paper also demonstrates the importance of the choice of the baseline. The capacity to mitigate GHG emissions will depend on baseline socioeconomic scenarios, including demographic, technological, and economic changes. This finding is consistent with the conceptual basis of the Shared Socio-economic Pathways (SSP). These scenarios which are currently developed to analyze climate policies are supposed to be contrasted in terms of capacity to mitigate GHG emissions (Ebi et al., 2013; O'Neill et al., 2013). This suggests that elasticities in energy-economy models are not set in stone: they will vary from one location to another depending on socio-economic evolutions and pre-existing conditions, and they can be affected by policies (especially infrastructure policies). Thus, this analysis can provide useful inputs to calibrate CGE models more precisely and as a function of the chosen scenario.

A key result of this paper is that without complementary policies a carbon or gasoline tax would need to be considerably higher to achieve a given objective of (relative) emissions reduction. Our results 
not only suggest that emissions are higher without a public transport system in place, but also that the ability to mitigate them is lower. These results confirm and expand findings from Gusdorf and Hallegatte (2007a), who showed that compact cities are less vulnerable to shocks in transport prices. They emphasize that synergies exist between transport and climate policies (Hallegatte et al., 2012): if we aim to increase gasoline prices in the future (e.g. through gasoline or carbon taxes) then the existence of a public transport network can significantly lower the costs. Considering recent failures to introduce carbon taxes (for example in France), it can even be argued that the absence of these complementary policies could prevent the implementation of environmental taxes entirely (Hammar et al., 2004).

Recent papers have suggested using a carbon tax (or revenues from cap-and-trade permit auctions) to raise government revenues to reduce debt and deficit or reduce other taxes (Carbone et al., 2012; Goulder, 1995; Rausch and Reilly, 2012). While revenue raising can be an additional motive for implementing carbon pricing and - under some conditions - generate a double dividend, it is important to note that different rationales for implementing a carbon tax lead to different incentives regarding complementary policies. If the carbon tax is implemented to change behaviors and reduce GHG emissions, it makes economic sense to complement it with policies that increase the price elasticity of carbon emissions, such as technology and innovation support or the type of infrastructure investments discussed in this paper. If the carbon tax is implemented to raise revenues (and to increase taxation of under-taxed rents and reduce taxation of overtaxed factors of production, see Edenhofer et al., 2013), then there is a disincentive to increase elasticity through such measures.

These results provide interesting input for policy makers in fast-growing cities in developing countries. Even if emission reductions are not a priority for them today, they need to take into account that their capacity to abate emissions in the future critically depends on the decisions they make today: in the absence of public transport investments and/or urbanization regulations, our results suggest they will face a low price elasticity of fuel consumption and GHG emissions. In other words, there exists an option value attached to a dense public transport network. This option value consists of the possibility of reducing emissions at a lower cost in the future.

These results are not only of relevance in the context of emission reduction, but also for mitigating the effects of rising oil prices and the impacts of other externalities such as congestion, accidents and air pollution. They suggest that where urban planning and public transport are concerned, "pollute now and clean up later" can be a very inefficient strategy (World Bank, 2012).

\section{References}

Acemoglu, D., Aghion, P., Bursztyn, L., Hemous, D., 2012. The Environment and Directed Technical Change. American Economic Review 102, 131-166. doi:10.1257/aer.102.1.131

Alonso, W., 1964. Location and land use: toward a general theory of land rent. Harvard University Press.

Anas, A., Hiramatsu, T., 2012. The effect of the price of gasoline on the urban economy: From route choice to general equilibrium. Transportation Research Part A: Policy and Practice 46, 855873. doi:10.1016/j.tra.2012.02.010

Anas, A., Liu, Y., 2007. A Regional Economy, Land Use, and Transportation Model (RELU-TRAN(C): Formulation, Algorithm Design, and Testing. Journal of Regional Science 47, 415-455. 
Anderson, S.T., Parry, I.W.H., Sallee, J.M., Fischer, C., 2011. Automobile Fuel Economy Standards: Impacts, Efficiency, and Alternatives. Rev Environ Econ Policy 5, 89-108. doi:10.1093/reep/req021

Baum-Snow, N., 2007. Suburbanization and transportation in the monocentric model. Journal of Urban Economics 62, 405-423. doi:10.1016/j.jue.2006.11.006

Bento, A., Kaffine, D., Roth, K., Zaragoza, M., 2013. The Unintended Consequences of Regulation in the Presence of Multiple Unpriced Externalities: Evidence from the Transportation Sector. The American Economic Journal: Economic Policy.

Bertaud, A., 2002. The spatial organization of cities: Deliberate outcome or unforeseen consequence? World Development Report 2003, background paper.

Brueckner, J.K., 2005. Transport subsidies, system choice, and urban sprawl. Regional Science and Urban Economics 35, 715-733. doi:10.1016/j.regsciurbeco.2005.01.001

Carbone, J.C., Morgenstern, R.D., Williams III, R.C., 2012. Carbon Taxes and Deficit Reduction. Unpublished Paper.

Cremer, H., Gahvari, F., Ladoux, N., 1998. Externalities and optimal taxation. Journal of Public Economics 70, 343-364.

Dahl, C., 1995. Demand for transportation fuels: a survey of demand elasticities and their components. Journal of Energy Literature 1, 3-27.

De Jong, G., Gunn, H., 2001. Recent evidence on car cost and time elasticities of travel demand in Europe. Journal of Transport Economics and Policy 137-160.

De Palma, A., Thisse, J.-F., 1987. Les modèles de choix discrets. Annales d'économie et de statistique.

DRIEA, 2005. Les déplacements des Franciliens en 2001 - 2002. Enquête Globale de Transports. Direction Régionale de l'Equipement lle-de-France.

Ebi, K.L., Hallegatte, S., Kram, T., Arnell, N.W., Carter, T.R., Edmonds, J., Kriegler, E., Mathur, R., O’Neill, B.C., Riahi, K., Winkler, H., Vuuren, D.P.V., Zwickel, T., 2013. A new scenario framework for climate change research: background, process, and future directions. Climatic Change 1-10. doi:10.1007/s10584-013-0912-3

Edenhofer, O., Mattauch, L., Siegmeier, J., 2013. Hypergeorgism: When is Rent Taxation as a Remedy for Insufficient Capital Accumulation Socially Optimal? CESifo, Center for Economic Studies \& Ifo Institute for economic research.

Ellaway, A., Macintyre, S., Hiscock, R., Kearns, A., 2003. In the driving seat: psychosocial benefits from private motor vehicle transport compared to public transport. Transportation Research Part F: Traffic Psychology and Behaviour 6, 217-231.

European Union, SOes, 2006. Corine Land Cover, 2006.

Fouquet, R., 2012. Trends in income and price elasticities of transport demand (1850-2010). Energy Policy 50, 62-71. doi:10.1016/j.enpol.2012.03.001

Fujita, M., 1989. Urban economic theory: land use and city size. Cambridge University Press, Cambridge, New York.

Goodwin, P., Dargay, J., Hanly, M., 2004. Elasticities of road traffic and fuel consumption with respect to price and income: a review. Transport Reviews 24, 275-292.

Goodwin, P.B., 1992. A review of new demand elasticities with special reference to short and long run effects of price changes. Journal of transport economics and policy 155-169.

Goulder, L.H., 1995. Effects of carbon taxes in an economy with prior tax distortions: an intertemporal general equilibrium analysis. Journal of Environmental economics and Management 29, 271-297.

Graham, D.J., Glaister, S., 2002. The demand for automobile fuel: a survey of elasticities. Journal of Transport Economics and policy 1-25.

Graham, D.J., Glaister, S., 2004. Road traffic demand elasticity estimates: a review. Transport reviews 24, 261-274.

Guivarch, C., Hallegatte, S., 2011. Existing infrastructure and the $2^{\circ} \mathrm{C}$ target. Climatic Change 109 , 801-805. doi:10.1007/s10584-011-0268-5 
Gusdorf, F., Hallegatte, S., 2007a. Compact or spread-out cities: Urban planning, taxation, and the vulnerability to transportation shocks. Energy Policy 35, 4826-4838. doi:10.1016/j.enpol.2007.04.017

Gusdorf, F., Hallegatte, S., 2007b. Behaviors and housing inertia are key factors in determining the consequences of a shock in transportation costs. Energy Policy 35, 3483-3495. doi:10.1016/j.enpol.2006.12.022

Gusdorf, F., Hallegatte, S., Lahellec, A., 2008. Time and space matter: How urban transitions create inequality. Global Environmental Change 18, 708-719. doi:10.1016/j.gloenvcha.2008.06.005

Hallegatte, S., Fay, M., Vogt-Schilb, A., 2013. Green Industrial Policies. The World Bank.

Hallegatte, S., Heal, G., Fay, M., Treguer, D., 2012. From Growth to Green Growth-a Framework (Policy Research Working Paper No. 5872), Background paper for the Flagship Report on Green Growth. World Bank, Washington DC.

Hammar, H., Löfgren, Å., Sterner, T., 2004. Political Economy Obstacles to Fuel Taxation. Energy Journal 25, 1-17.

Hughes, J.E., Knittel, C.R., Sperling, D., 2008. Evidence of a shift in the short-run price elasticity of gasoline demand. Energy Journal 29, 113-134.

IAU îdF, Région Île de France, 2011. L'environnement en Île de France - Mémento 2011. Institut d'Aménagement Urbain de la Région lle de France.

IMF, 2013. Energy Subsidy Reform: Lessons and Implications. International Monetary Fund, Washington, D.C.

Interagency Working Group on Social Cost of Carbon, US Government, 2010. Technical Support Document: Social Cost of Carbon for Regulatory Impact Analysis Under Executive Order 12866, 2.

Jenkins, J.D., 2014. Political economy constraints on carbon pricing policies: What are the implications for economic efficiency, environmental efficacy, and climate policy design? Energy Policy 69, 467-477. doi:10.1016/j.enpol.2014.02.003

Kaya, Y., Yokobori, K., 1997. Environment, Energy and Economy; Strategies for Sustainability. United Nations University Press.

Kopp, A., Block, R.I., limi, A., 2013. Turning the right corner: ensuring development through a lowcarbon transport sector, Directions in development, environment and sustainable development. World Bank, Washington, D.C.

Lecocq, F., Shalizi, Z., 2014. The economics of targeted mitigation in infrastructure. Climate Policy 14, 187-208. doi:10.1080/14693062.2014.861657

Li, S., Timmins, C., Roger H. von Haefen, 2009. How Do Gasoline Prices Affect Fleet Fuel Economy? American Economic Journal: Economic Policy 1, 113-137. doi:10.2307/25760042

Mills, E.S., 1967. An Aggregative Model of Resource Allocation in a Metropolitan Area. The American Economic Review 57, 197-210.

Muth, R.F., 1969. Cities and housing; the spatial pattern of urban residential land use. University of Chicago Press, Chicago.

Nordhaus, W.D., 2008. A question of balance: Weighing the options on global warming policies. Yale University Press.

Nowak, W.P., Savage, I., 2013. The cross elasticity between gasoline prices and transit use: Evidence from Chicago. Transport Policy 29, 38-45.

O'Neill, B.C., Kriegler, E., Riahi, K., Ebi, K.L., Hallegatte, S., Carter, T.R., Mathur, R., Vuuren, D.P., 2013. A new scenario framework for climate change research: the concept of shared socioeconomic pathways. Climatic Change 1 - 14. doi:10.1007/s10584-013-0905-2

Perrissin Fabert, B., Dumas, P., Hourcade, J.-C., 2012. What social cost of carbon? a mapping of the climate debate. Nota di lavoro, Fondazione Eni Enrico Mattei: Climate Change and Sustainable Development.

Pigou, A.C., 1920. The economics of welfare. Macmillan and Co., London.

Pindyck, R.S., 2013. Climate Change Policy: What Do the Models Tell Us? Journal of Economic Literature 51, 860-872. doi:10.1257/jel.51.3.860 
Ramsey, F.P., 1927. A Contribution to the Theory of Taxation. The Economic Journal 37, 47-61.

Rausch, S., Reilly, J., 2012. Carbon tax revenue and the budget deficit: A win-win-win solution? MIT Joint Program on the Science and Policy of Global Change.

Rozenberg, J., Hallegatte, S., Vogt-Schilb, A., Sassi, O., Guivarch, C., Waisman, H., Hourcade, J.-C., 2010. Climate policies as a hedge against the uncertainty on future oil supply. Climatic Change 101, 663-668. doi:10.1007/s10584-010-9868-8

Rozenberg, J., Vogt-Schilb, A., Hallegatte, S., 2014. Transition to Clean Capital, Irreversible Investment and Stranded Assets (SSRN Scholarly Paper No. ID 2433812). Social Science Research Network, Rochester, NY.

Salon, D., 2009. Neighborhoods, cars, and commuting in New York City: A discrete choice approach. Transportation Research Part A: Policy and Practice 43, 180-196.

Sandmo, A., 1975. Optimal taxation in the presence of externalities. The Swedish Journal of Economics 86-98.

Schipper, L., Marie-Lilliu, C., Gorham, R., 2000. Flexing the link between transport and greenhouse gas emissions. IEA.

Sterner, T., 2007. Fuel taxes: An important instrument for climate policy. Energy Policy 35, 31943202. doi:10.1016/j.enpol.2006.10.025

Tol, R.S., 2005. The marginal damage costs of carbon dioxide emissions: an assessment of the uncertainties. Energy policy 33, 2064-2074.

Turton, H., Moura, F., 2008. Vehicle-to-grid systems for sustainable development: An integrated energy analysis. Technological Forecasting and Social Change 75, 1091-1108.

Viguié, V., Hallegatte, S., 2012. Trade-offs and synergies in urban climate policies. Nature Climate Change 2, 334-337. doi:10.1038/nclimate1434

Viguié, V., Hallegatte, S., Rozenberg, J., 2014. Downscaling long term socio-economic scenarios at city scale: A case study on Paris. Technological Forecasting and Social Change. doi:10.1016/j.techfore.2013.12.028

Vogt-Schilb, A., Hallegatte, S., 2014. Marginal abatement cost curves and the optimal timing of mitigation measures. Energy Policy 66, 645-653. doi:10.1016/j.enpol.2013.11.045

Vogt-Schilb, A., Hallegatte, S., De Gouvello, C., 2014. Long-term mitigation strategies and marginal abatement cost curves: a case study on Brazil. World Bank Policy Research Working Papers.

Vogt-Schilb, A., Meunier, G., Hallegatte, S., 2012. How inertia and limited potentials affect the timing of sectoral abatements in optimal climate policy. World Bank Policy Research Working Paper.

Vogt-Schilb, A., Meunier, G., Hallegatte, S., 2013. Optimal timing, cost and sectoral distribution of emission reductions: abatement cost curves vs. abatement investment. ASSA.

Waisman, H., Guivarch, C., Grazi, F., Hourcade, J.-C., 2012. The IMACLIM-R model: infrastructures, technical inertia and the costs of low carbon futures under imperfect foresight. Climatic Change 114, 101-120. doi:10.1007/s10584-011-0387-z

Washbrook, K., Haider, W., Jaccard, M., 2006. Estimating commuter mode choice: A discrete choice analysis of the impact of road pricing and parking charges. Transportation 33, 621-639.

World Bank, 2012. Inclusive green growth: the pathway to sustainable development. World Bank, Washington, D.C.

Zhang, M., 2004. The role of land use in travel mode choice: evidence from Boston and Hong Kong. Journal of the American Planning Association 70, 344-360. 